Original investigation

Open Access

\title{
Aminoguanidine inhibits aortic hydrogen peroxide production, VSMC NOX activity and hypercontractility in diabetic mice Jeong-Ho Oak ${ }^{1,2}$, Ji-Youn Youn ${ }^{1,2}$ and Hua Cai*1,2
}

Address: ${ }^{1}$ Department of Anesthesiology, David Geffen School of Medicine at University of California Los Angeles (UCLA), Los Angeles, CA, USA and ${ }^{2}$ Department Medicine, David Geffen School of Medicine at University of California Los Angeles (UCLA), Los Angeles, CA, USA

Email: Jeong-Ho Oak - Oak_Jeong-ho@takeda.co.jp; Ji-Youn Youn - jyyoun@ucla.edu; Hua Cai* - hcai@mednet.ucla.edu

* Corresponding author

Published: 30 December 2009

Cardiovascular Diabetology 2009, 8:65 doi:10.1 I86/1475-2840-8-65

This article is available from: http://www.cardiab.com/content/8/I/65

(C) 2009 Oak et al; licensee BioMed Central Ltd.

This is an Open Access article distributed under the terms of the Creative Commons Attribution License (http://creativecommons.org/licenses/by/2.0), which permits unrestricted use, distribution, and reproduction in any medium, provided the original work is properly cited.
Received: 31 July 2009

Accepted: 30 December 2009

\begin{abstract}
Background: Dysfunctionally uncoupled endothelial nitric oxide synthase (eNOS) is involved in producing reactive oxygen species (ROS) in the diabetic endothelium. The present study investigated whether anti-diabetes drug Aminoguanidine (AG) has any effect on eNOS function and vascular oxidant stress.

Methods and Results: Blood glucose levels were increased to $452.0 \pm 15.1 \mathrm{mg} / \mathrm{dl}$ in STZ-treated male C57BL/6 Jice ( $148.4 \pm 3.2 \mathrm{mg} / \mathrm{dl}$ in untreated controls). Aortic productions of $\mathrm{NO}$ and $\mathrm{O}_{2}{ }^{-}$ were measured specifically and sensitively using electron spin resonance. Diabetic mice had a marked increase in aortic $\mathrm{O}_{2}{ }^{-}$-production. Aortic hydrogen peroxide $\left(\mathrm{H}_{2} \mathrm{O}_{2}\right)$ production was also increased in diabetic aortas and significantly attenuated by AG. AG however had only a marginal effect in reducing aortic $\mathrm{O}_{2}{ }^{-}$production, which corresponded to a minimal effect in improving aortic nitric oxide (NO') bioavailability. The endothelium-dependent vasodilatation however was modestly but significantly improved by AG, likely consequent to AG-induced reduction in hypercontractility. $\mathrm{NAD}(\mathrm{P}) \mathrm{H}$ oxidase (NOX)-dependent $\mathrm{O}_{2}{ }^{\cdot-}$ production was completely attenuated by AG in endothelium-denuded diabetic aortas.

Conclusion: In summary, despite that AG is not an effective eNOS recoupling agent presumably consequent to its ineffectiveness in preventing endothelial NOX activation, it is inhibitory of aortic $\mathrm{H}_{2} \mathrm{O}_{2}$ production, VSMC NOX activity, and hypercontractility in diabetes.
\end{abstract}

\section{Background}

Cardiovascular complications are the primary causes of mortality in diabetic patients $[1,2]$. Accumulating evidence has demonstrated that increased production of reactive oxygen species (ROS) contributes to etiology of diabetes [3-6] and its cardiovascular complications [4,611]. Various enzymatic systems have been shown responsible for diabetic oxidant stress, including xanthine oxidase [12], $\mathrm{NAD}(\mathrm{P}) \mathrm{H}$ oxidase $[13,14]$, and the more recently established, uncoupled endothelial nitric oxide synthase (eNOS) $[15,16]$. Oxidant stress contributes to diabetic vascular damages by acceleration of advanced glycation end products (AGEs) formation, modulation of extracellular matrix proteins, promotion of cell proliferation and migration, stimulation of kinases and proinflammatory proteins, and importantly, inactivation of nitric oxide $\left(\mathrm{NO}^{\bullet}\right)$, all of which are closely associated with the pathogenesis of diabetic vascular complications $[17,18]$. 
Aminoguanidine (AG) is one of the most extensively used inhibitors of AGEs accumulation. Beneficial effects in preventing cardiovascular events in diabetic rats have been observed with AG treatment, likely attributed to its effects on stopping AGE formation [19]. Besides its inhibitory action on AGE formation, AG acts as a competitive and selective inhibitor for inducible nitric oxide synthase (iNOS) [20]. This action of AG has been known to be associated with reduction of peroxinitrite (ONOO-), which has deleterious roles in inducing $\mathrm{NO}^{\bullet}$ deficiency and cellular damages through degradation of eNOS cofactor, and inductions of inflammation, lipid peroxidation, protein nitrosylation and DNA fragmentation $[18,21,22]$. Previous investigations have also demonstrated that AG reduced hydrogen peroxide $\left(\mathrm{H}_{2} \mathrm{O}_{2}\right)$ induced intracellular hydroxyl radical formation and apoptosis, further demonstrating a potential antioxidant activity $[23,24]$. These multiple actions of AG may improve endothelial function in diabetes independent of its AGE-inhibiting activity $[22,23]$. Apart from its beneficial effects, high dose of AG is associated with some adverse effects such as autoimmune symptoms, abnormal liver function, gastrointestinal disturbance, and flu-like symptoms $[25,26]$. These side effects are likely related to its structural similarities to hydrazine, an inducing factor of lupus like syndrome, and L-arginine, a substrate of NO synthase [27]. Thus the potential effect of AG is complex in diabetes associated cardiovascular complication. The direct impact of AG on aortic oxidant stress and eNOS function is completely unknown despite that AG was found to suppress superoxide $\left(\mathrm{O}_{2}{ }^{\bullet}\right)$ production, mitochondrial complex III activity and eNOS uncoupling in the kidney $[26,28]$.

Therefore, in the present study we treated STZ-induced diabetic mice in vivo with $\mathrm{AG}$, and measured aortic $\mathrm{O}_{2}{ }^{\circ}$ and $\mathrm{NO}{ }^{\bullet}$ productions by electron spin resonance (ESR) sensitively and specifically. AG only marginally reduced total aortic $\mathrm{O}_{2}{ }^{-}$- production although it significantly attenuated aortic hydrogen peroxide $\left(\mathrm{H}_{2} \mathrm{O}_{2}\right)$ generation. Endothelium-dependent vasodilatation was modestly yet significantly improved which was accompanied by AG-dependent significant reduction in aortic hypercontractility. $\underline{\mathrm{NAD}}(\mathrm{P}) \mathrm{H}$ oxidase (NOX)dependent $\mathrm{O}_{2}{ }^{\circ}$ - production in endothelium-denuded aortas was significantly attenuated by AG, likely contributing to the reduction in phenylephrine (PE)-induced hypercontractility. These data seem to implicate that although AG is ineffective in recoupling eNOS in diabetic aortas, it reduces vascular $\mathrm{H}_{2} \mathrm{O}_{2}$ production and hypercontractility in diabetes, which may in part account for its beneficial effects in preventing vascular disease development.

\section{Methods}

\section{Diabetic mice and drug interventions}

Male C57BL/6J mice (6-8 weeks old) were obtained from Jackson Laboratories. Mice were housed in a pathogenfree condition. The Institutional Animal Care and Usage
Committee at the University of Chicago and University of California Los Angeles approved the use of animals and experimental procedures. Diabetes was induced by tail vein injection of Streptozocin (STZ, $100 \mathrm{mg} / \mathrm{Kg}$ ) dissolved in $50 \mu \mathrm{L}$ of $0.9 \%$ saline immediately before use, once a day for three days $[15,29,30]$. Blood glucose was determined using the One Touch Ultra ${ }^{\circledR}$ blood glucose meter (Lifescan) at baseline and on day four post STZ injection for each individual mouse. On day four, STZ diabetic mice were injected with Aminoguanidine (AG) [31] dissolved in $0.9 \%$ saline via tail vein at $100 \mathrm{mg} / \mathrm{kg} / \mathrm{day}$ for three days. By day seven, animals were sacrificed using $\mathrm{CO}_{2}$ inhalation and whole aorta was removed, cleared from surrounding connective tissues and cut transversely into 2 $\mathrm{mm}$ or $3 \mathrm{~mm}$ rings for subsequent experiments. Nitric oxide production and vasoreactivity measurement was performed with $2 \mathrm{~mm}$ of aorta segments and determination of superoxide and hydrogen peroxide level was conducted with each $3 \mathrm{~mm}$ of aorta. This model of diabetes is characterized by acute hyperglycemia. No renal dysfunction occurs during the study period of seven days [32].

\section{Electron spin resonance measurement of aortic superoxide production}

Freshly isolated aortas were placed into chilled modified Krebs/HEPES buffer (composition in mmol/L: 99.01 $\mathrm{NaCl}, 4.69 \mathrm{KCl}, 2.50 \mathrm{CaCl}_{2}, 1.20 \mathrm{MgSO}_{4}, 1.03 \mathrm{KH}_{2} \mathrm{PO}_{4}$ $25.0 \mathrm{NaHCO}_{3}, 20.0 \mathrm{Na}$-HEPES, and 5.6 glucose [pH $7.4]$ ), cleaned of excessive adventitial tissue, with care taken not to injure the endothelium. The specific $\mathrm{O}_{2}{ }^{\circ}$-spin trap methoxycarbonyl-2,2,5,5-tetramethyl-pyrrolidine (CMH, $500 \mu \mathrm{mol} / \mathrm{L}$, Alexis) solution was prepared freshly in nitrogen gas bubbled Krebs/HEPEs buffer containing diethyldithiocarbamic acid (DETC, $5 \mu \mathrm{mol} / \mathrm{L}$ Sigma) and deferoxamine (25 $\mu \mathrm{mol} / \mathrm{L}$, Sigma). Aortic segment ( 3 $\mathrm{mm}$ ) was then mixed with the spin trap solution and loaded into glass capillary (Fisher Scientific) for analysis of $\mathrm{O}_{2}{ }^{\bullet}$ signal $\left(\mathrm{CM}^{\bullet}\right.$ formed after trapping $\left.\mathrm{O}_{2}{ }^{\bullet}\right)$ using the electron spin resonance (ESR) spectrometer (Miniscope MS200, Magnettech, Germany). Some of the intact or endothelium-denuded aortic segments were incubated in presence or absence of NSC23766 (200 nmol/L, $90 \mathrm{~min})$ to detect NOX sensitive superoxide production. The ESR settings used were bio-field, 3350; field sweep, 45.00 G (1 $\mathrm{G}=0.1 \mathrm{mT}$ ); microwave frequency, $9.78 \mathrm{GHz}$; microwave power $7 \mathrm{~dB}(20 \mathrm{~mW})$; modulation amplitude, $3000 \mathrm{mG}$; 4,096 points of resolution; and receiver gain, 700 .

\section{Amplex-Red assay for hydrogen peroxide production}

Freshly isolated aortic rings $(4 \times 2 \mathrm{~mm})$ were used for assessment of $\mathrm{H}_{2} \mathrm{O}_{2}$ production using a fluorometric horseradish peroxidase assay (Amplex-Red assay, Molecular Probes). Fluorescence was measured (excitation 530 $\mathrm{nm}$ and emission $590 \mathrm{~nm}$ ) after 1 hour incubation at $37^{\circ} \mathrm{C}$ in dark against background fluorescence of buffer. Polyethylene glycol conjugated catalase (PEG-CAT, 300 
$\mathrm{U} / \mathrm{ml}$, Sigma)-inhibitable fraction reflects specific $\mathrm{H}_{2} \mathrm{O}_{2}$ signal. The rate of $\mathrm{H}_{2} \mathrm{O}_{2}$ production was presented as $\mathrm{pmol} / \mathrm{mg}$ protein/min after calculation according to a standard curve generated using fresh $\mathrm{H}_{2} \mathrm{O}_{2}$ in reaction buffer [33].

\section{Electron spin resonance of aortic nitric oxide production} Freshly isolated aortic rings $(6 \times 2 \mathrm{~mm})$ were incubated with freshly prepared $\mathrm{NO}^{\bullet}$-specific spin trap $\mathrm{Fe}^{2+}(\mathrm{DETC})_{2}$ $(0.5 \mathrm{mmol} / \mathrm{L})$ in modified Kreb's HEPES buffer (KHB) at $37^{\circ} \mathrm{C}$ for $60 \mathrm{~min}$ [spin trap and buffer recipe see above and previous publication [34], in the presence or absence of calcium ionophore A23187 $(10 \mu \mathrm{mol} / \mathrm{L})$. After the incubation, the aorta in KHB was snap-frozen in liquid nitrogen and loaded into a finger Dewar for analysis with ESR spectrophotometer. The instrument settings were as the followings: bio-field, 3280; field sweep, 77.54 G (1 G $=0.1 \mathrm{mT}$ ); microwave frequency, $9.78 \mathrm{GHz}$; microwave power, $4 \mathrm{~dB}(40 \mathrm{~mW})$; modulation amplitude, $10 \mathrm{G}$; 4,096 points of resolution; and receiver gain, 900 .

\section{Assessment of vascular reactivity}

Freshly prepared aortic rings $(2 \mathrm{~mm}$ ) were placed in organ baths containing modified Kreb's HEPES buffer(recipe see above), aerated with a mixture of $95 \%$ oxygen $/ 5 \%$ carbon dioxide and maintained at $37^{\circ} \mathrm{C}$. After being kept under 5 $\mathrm{mN}$ tension for $90 \mathrm{~min}$ to stabilize, cumulative tension was measured by a Graz Tissue Bath System (Hugo Sachs Elektronik/Harvard Apparatus GmbH, March Hugstetten, Germany) connected to a The MP100 workstations (BioPac Systems). Relaxation curve to acetylcholine (10-9 to $10^{-6} \mathrm{M}$ ) were assessed in aortic segment after contraction by phenylephrine (PE, $5 \mu \mathrm{mol} / \mathrm{L}$ ). Data acquisition process and post-acquisition calculations were performed with AcqKnowledge software (BioPac Systems).

\section{Statistical analysis}

Differences among different groups of means were compared with unpaired $t$-test for two means and ANOVA for multiple means. Statistical significance was set for $\mathrm{p}<$ 0.05. All grouped data shown in the figures were presented as mean \pm SEM.

\section{Results \\ Effect of Aminoguanidine on hyperglycemia}

Diabetic mice were created by streptozotocin (STZ) administration. On day of harvest $\left(7-8^{\text {th }}\right.$ day after initial STZ injection, same hereafter), blood glucose was elevated to $452.0 \pm 15.1 \mathrm{mg} / \mathrm{dl}$ in diabetic mice vs $148.4 \pm 3.2 \mathrm{mg} /$ $\mathrm{dl}$ in the C57BL6 controls. AG $(100 \mathrm{mg} / \mathrm{kg} /$ day, same hereafter) treatment since day 4 had no significant effect on STZ induction of hyperglycemia (data not shown).

Effect of Aminoguanidine on aortic superoxide production Aortic production of $\mathrm{O}_{2}{ }^{\bullet}$, etected specifically by electron spin resonance (ESR) and a cell-permeable specific spin trap, was more than doubled in diabetic mice (control vs diabetics: $3.3 \pm 1.6$ vs $7.0 \pm 2.6 \mathrm{nmol} / \mathrm{L}$ per min per $\mathrm{mg}$ wet weight of aorta, $p<0.05)$. AG attenuated this response however marginally and insignificantly, as demonstrated by both representative ESR spectra and grouped data (Figs. 1A\&B).

\section{Effect of Aminoguanidine on aortic hydrogen peroxide production}

Aortic $\mathrm{H}_{2} \mathrm{O}_{2}$ was detected specifically using an Amplex Red Assay (details see Methods section). Diabetic mice had a more than 4 -fold increase in $\mathrm{H}_{2} \mathrm{O}_{2}$ production (5.86 $\pm 1.21 \mathrm{vs} 22.39 \pm 3.61 \mathrm{pmol} / \mathrm{mg}$ protein $/ \mathrm{min}$ for control vs diabetics), which was significantly attenuated by treatment with AG $(9.77 \pm 4.71 \mathrm{pmol} / \mathrm{mg}$ protein $/ \mathrm{min}$, Fig. $2 \mathrm{~A}, \mathrm{p}<0.05)$.

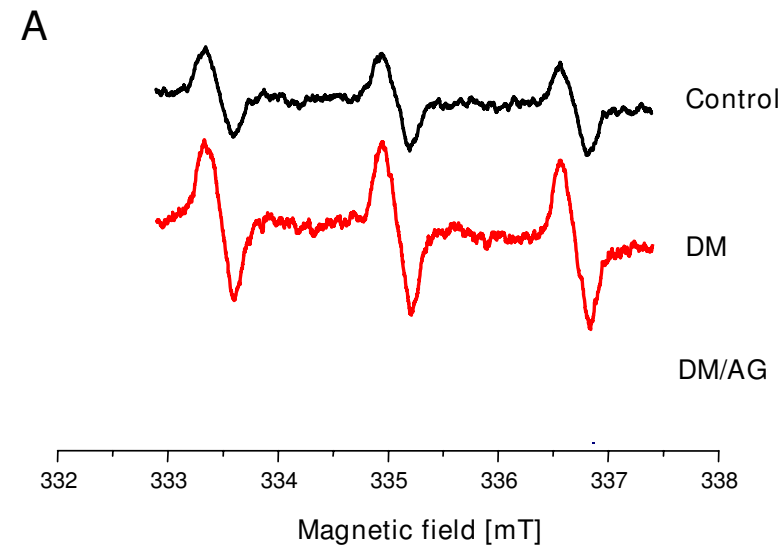

B

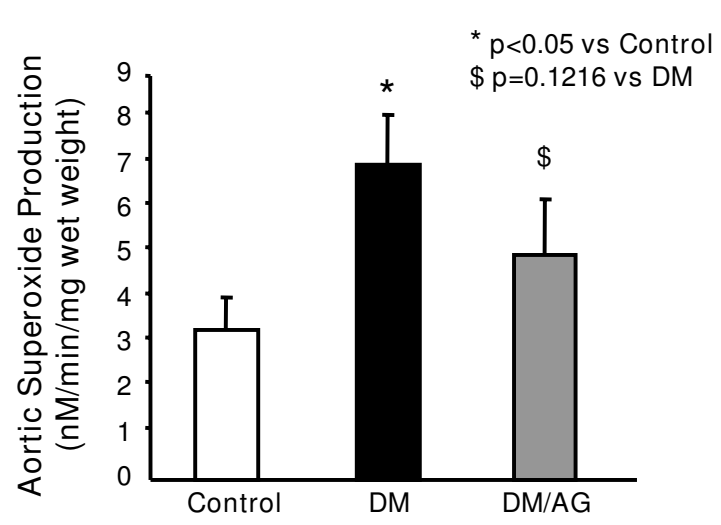

\section{Figure I}

Effects of AG on aortic superoxide $\left(\mathrm{O}_{2}{ }^{-*}\right)$ production. A: Representative spectra for aortic $\mathrm{O}_{2}{ }^{-}$- detected by ESR. Freshly isolated aortic segments $(\sim 3 \mathrm{~mm})$ were incubated with spin trapping solution and then analyzed using ESR. B: Grouped data of aortic $\mathrm{O}_{2}{ }^{-}$production expressed as $\mathrm{nmol} / \mathrm{L}$ per min per mg wet weight. Data are presented as mean \pm SEM, $n=6-8$. 


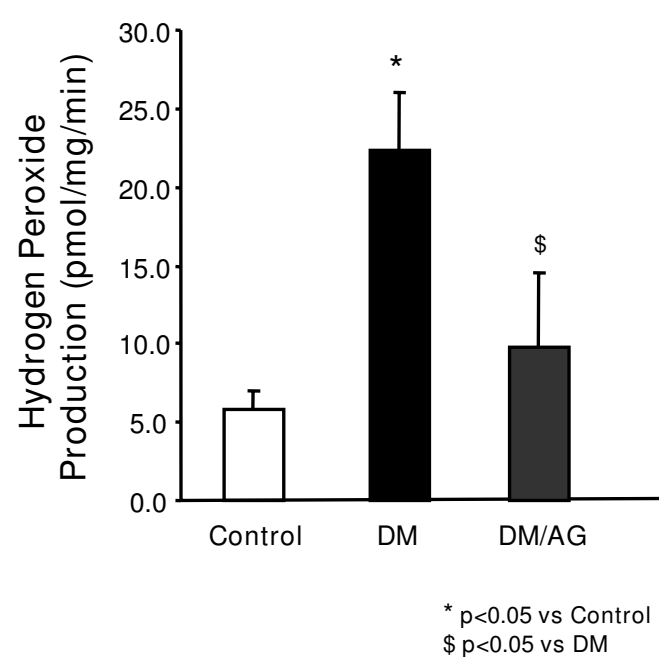

Figure 2

Effects of AG on aortic hydrogen peroxide $\left(\mathrm{H}_{2} \mathrm{O}_{2}\right)$ production. Total aortic $\mathrm{H}_{2} \mathrm{O}_{2}$ production by Amplex Red Assay. Data are presented as mean \pm SEM, $n=8$.

Aminoguanidine failed to restore aortic NO production Aortic $\mathrm{NO}^{\bullet}$ production was directly and characteristically detected using ESR. As shown in representative ESR spectra and grouped data (Figs. 3A\&B), diabetic mice had markedly reduced bioavailable $\mathrm{NO} \bullet(0.50 \pm 0.08$ in diabetes vs $0.72 \pm 0.10 \mathrm{nmol} / \mathrm{mg}$ dry weight) and this response

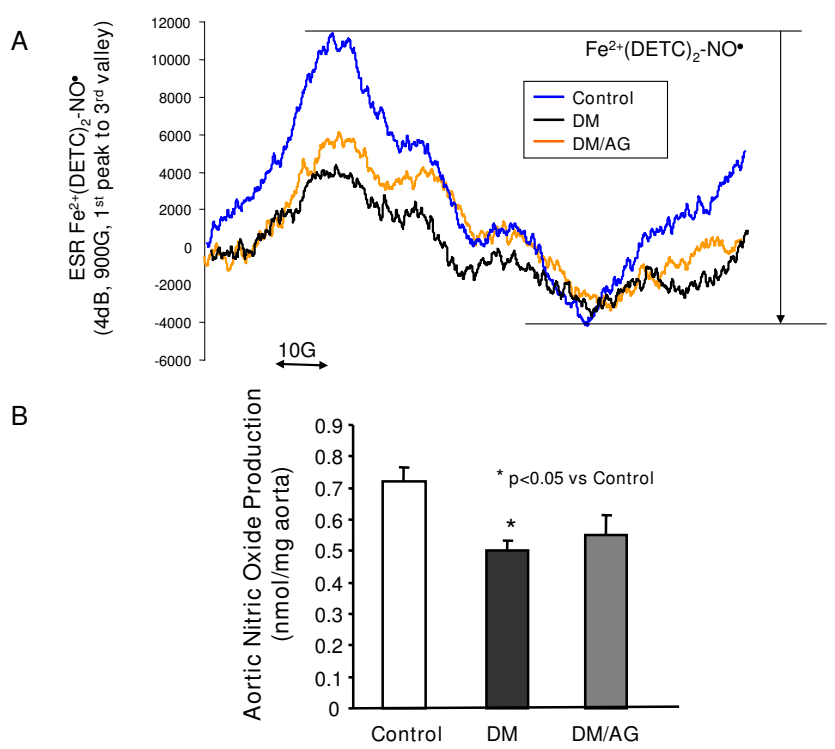

Figure 3

Effects of AG on aortic nitric oxide (NO') bioavailability in diabetes. A: Representative ESR spectra for NO; B: Grouped data of bioavailable NO. Data are presented as mean \pm SEM, $n=6$. was however not significantly affected by treatment with AG $(0.55 \pm 0.15 \mathrm{nmol} / \mathrm{mg}$ dry weight $)$. This result indicated that AG was ineffective in fully restoring eNOS function.

\section{Aminoguanidine partially restored endothelium- dependent vasorelaxation: Role of attenuation of hypercontractility?}

Interestingly, although AG did not protect $\mathrm{NO} \bullet$ bioavailability likely due to its insignificance in reducing $\mathrm{O}_{2}{ }^{\bullet-}$ production from eNOS, AG partially yet significantly restored endothelium-dependent vasorelaxation (Fig. 4A). Intriguingly, diabetic aortas exerted a more than 3-fold increase in basal contractility in response to PE, which was markedly attenuated by AG (Fig. 4B). Vascular smooth muscle cell (VSMC) production of $\mathrm{O}_{2}{ }^{\bullet-}$ has been implicated in the hypercontractile response in diabetic blood vessels $[35,36]$. Furthermore, the source of this $\mathrm{O}_{2}{ }^{\bullet-}$ production could be NAD(P)H oxidase (NOX) [35]. Previously we have successfully measured $\mathrm{O}_{2}{ }^{\bullet-}$ production from endothelium-denuded vessels in the presence of NOX inhibitor. As shown in Fig. 5, consistent to previous findings, NOX remained active in VSMC [16]. AG completely diminished NSC23766-sensitive $\mathrm{O}_{2} \bullet$ production, indicating that attenuation of NOX may have accounted for reduced hypercontracility observed with $A G$, which was further linked to improved vasorelaxation.

It is important to emphasize that in the intact endothelium, uncoupled eNOS is the primary source of ROS production 7 days after STZ injection [16]. This is presumably consequent to a transient activation of endothelial NOX based on our in vitro data from cultured aortic endothelial cells [34]. In this earlier study we found that, via transient activation endothelial NOX, angiotensin II (Ang II) induces $\mathrm{H}_{2} \mathrm{O}_{2}$ dependent eNOS uncoupling. Indeed, we found that in vivo treatment with Ang II signaling attenuators candesartan or captopril completely prevented eNOS uncoupling in diabetes [16].

We also found that after removal of endothelium to allow sufficient spin trap penetration to the underneath VSMC, NOX-dependent $\mathrm{O}_{2}{ }^{\bullet-}$ production remained elevated by day 7 , which was found attenuated by candesartan or captopril previously, and now by AG. Therefore we believe that although AG may not have any effects on the endothelial NOX isoform in contrast to the Ang II attenuators, it is effective in inhibiting the VSMC NOX isoform. We are working on follow-up studies to identify cell-specific NOX isoforms that are involved in the eNOS uncoupling and NOX activation in diabetic endothelial cells and VSMC. These would be however beyond the scope of the present study.

\section{Discussion}

The present study systematically studied effects of AG on vascular oxidant stress, eNOS function and endothelium- 
A

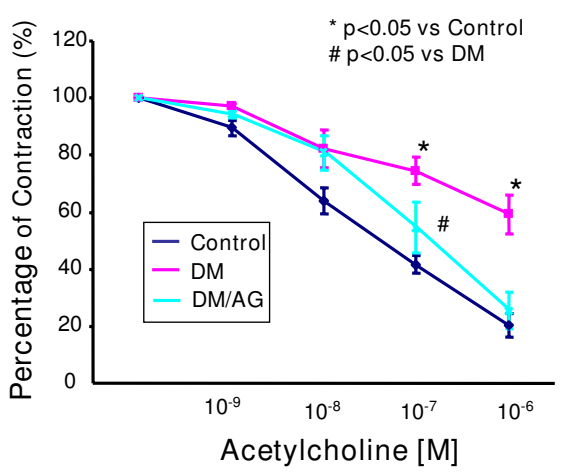

B

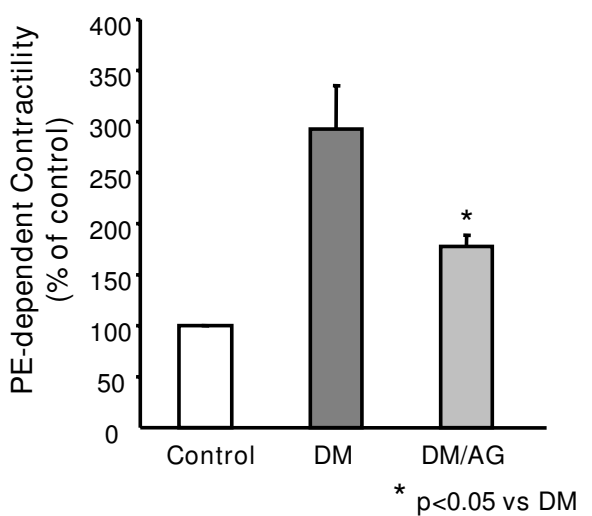

\section{Figure 4}

Effects of AG on vascular reactivity. A: AG partially restored endothelium-dependent vasorelaxation. B: AG diminished diabetes induced aortic hypercontractility. Data are presented as mean $\pm S E M, n=6$.

dependent vasorelaxation. Whereas AG only partially reduced vascular $\mathrm{O}_{2} \cdot$ - production, it attenuated $\mathrm{H}_{2} \mathrm{O}_{2}$ production significantly and improved endothelium-dependent vasodilatation, likely via a reduction in NOX-linked

A

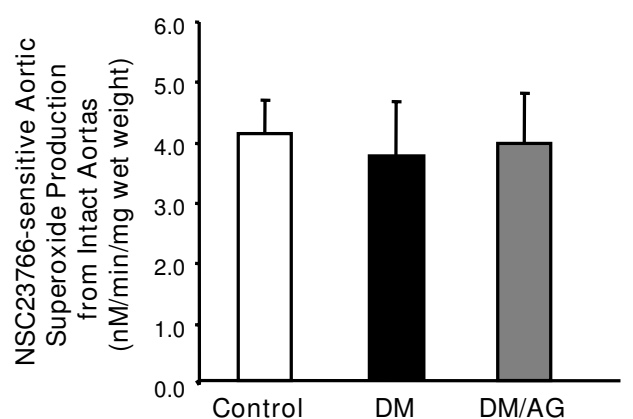

B

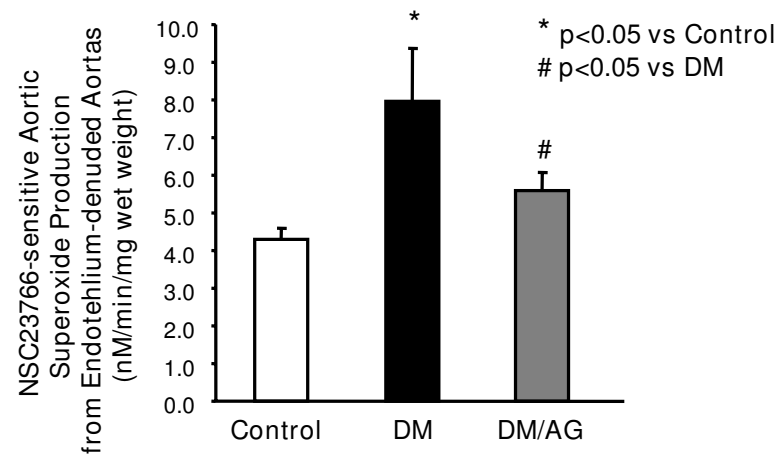

\section{Figure 5}

Effects of AG on NOX-sensitive superoxide $\left(\mathrm{O}_{2}{ }^{\circ-}\right)$ production. A: NSC23766-sensitive $\mathrm{O}_{2}{ }^{-}$- production from intact aortas B: NSC23766-sensitive $\mathrm{O}_{2}{ }^{--}$production from endothelium denuded aortas. Data are presented as mean \pm SEM, $n=6$. hypercontractility. Although AG does not seem to be an effective eNOS recoupling agent like Ang II signaling attenuators [16], it may still exert beneficial effects via attenuating VSMC NOX activity and $\mathrm{H}_{2} \mathrm{O}_{2}$ production.

Oxidant stress has been implicated in micro and macrovascular complication of diabetes [37]. Moreover, excessive generation of $\mathrm{O}_{2}{ }^{-}$in endothelium by hyperglycemia has been considered one of the major factors involved in accelerating vascular complications. Recent studies have shown that eNOS uncoupling is the primary source of $\mathrm{O}_{2}{ }^{-}$- production in the diabetic endothelium $[15,16]$, whereas $\mathrm{NAD}(\mathrm{P}) \mathrm{H}$ oxidase remain active in sub-endothelial VSMC [16]. eNOS uncoupling is a phenomenon whereby the enzyme generates $\mathrm{O}_{2}{ }^{-}$rather than $\mathrm{NO}{ }^{\bullet}$. Previously we established that increased $\mathrm{O}_{2}{ }^{-}$production in STZ-induced diabetic mice is attributed to eNOS uncoupling, which was significantly attenuated by Ang II signaling blockers [16]. In the present study we examined effects of AGE chain breaker AG in recoupling eNOS and found AG failed to significantly reduce aortic $\mathrm{O}_{2}{ }^{-}$production in diabetes. AG also failed to significantly restore aortic $\mathrm{NO}{ }^{\bullet}$ bioavailability. AG has been used as a iNOS inhibitor because of its structure similarity with L-arginine; and it is also known as a weaker inhibitor for eNOS $[27,38]$. Whether or not these are linked to the ineffectiveness of AG in restoring $\mathrm{NO}{ }^{\bullet}$ production however, remain unclear.

Despite lack of significant impacts on $\mathrm{O}_{2} \bullet / \mathrm{NO} \bullet$ pathway, AG significantly attenuated aortic $\mathrm{H}_{2} \mathrm{O}_{2}$ production in diabetic mice. It also significantly, though modestly, improved endothelium-dependent vasodilatation, which is likely consequent to a reduction in hypercontractility that is associated with attenuation of VSMC NOX activity. Ineffective eNOS recoupling agent that is, AG proved to be 
highly effective in attenuating diabetes-induced aortic hypercontractility.

There have been controversial observations of diabetic hypercontracility given species, age, diabetic type, diabetic stage, and vessel types [14,39-43]. For instance, a recent study by Su et al., showed that acetylcholine dependent dilation was decreased in diabetes whereas there was no difference between control and diabetic group in response to PE, concluding no specific role of VSMC contraction in type 2 diabetes [14]. Not in agreement with our data, they observed that AG did not alter vasocontraction to PE, indicating that AGE formation is not associated with muscle contraction in type 2 diabetic mesenteric arteries [14]. On the other hand, other studies demonstrated hypercontractility to PE in aortas of STZ-induced diabetes $[44,45]$. In agreement with our results, AG normalized the response to PE in STZ diabetic mice without affecting plasma glucose levels [44]. Taken together, our results are consistent with previous observations regarding effect of AG on vascular hypercontraction in conduit vessels of early stage type 1 diabetes, hence indicating a potential beneficial effect of AG for prevention of cardiovascular complication for this particular diabetic type and stage.

It has been hypothesized that the basal hypercontractility is dependent on $\mathrm{O}_{2}{ }^{-}$-in STZ induced diabetic mice [36]. In the denuded aortas of human diabetes, $\mathrm{O}_{2}{ }^{\bullet}$ production was also found elevated [35]. Indeed we have observed that in the endothelium-denuded aortas, AG completely attenuated NOX dependent $\mathrm{O}_{2}{ }^{\bullet-}$ production from VSMC (Fig. 5). Theoretically this reduction in $\mathrm{O}_{2}{ }^{-}$could feed back to the endothelium to partially contribute to preservation of $\mathrm{NO}^{\bullet}$ bioavailability. On the other hand, loss of $\mathrm{O}_{2}{ }^{\bullet}$ in VSMC may directly modulate VSMC contractility via undefined mechanisms. It is interesting to speculate that loss of NOX-derived $\mathrm{O}_{2}{ }^{*}$ in diabetic VSMC might underlie AG reduction of hypercontractility.

\section{Conclusion}

In summary, AG has been examined systematically for its effects on vascular oxidant stress, eNOS function and endothelium-dependent vasorelaxation. To our knowledge these are first endeavors. This agent was ineffective in reducing plasma glucose levels, partially effective in inhibiting total $\mathrm{O}_{2}{ }^{\bullet}$, and insignificantly effective in improving $\mathrm{NO} \bullet$ bioavailability in diabetes. However, it reduced aortic $\mathrm{H}_{2} \mathrm{O}_{2}$ production and improved endothelium-dependent vasorelaxation while diminished hypercontractility of aortas. Whether this is attributed to AG-dependent significant reduction in VSMC NOX activity remains to be further elucidated.

\section{Competing interests}

The authors declare that they have no competing interests.

\section{Authors' contributions}

JHO collected data and performed data analysis. JYY participated in data analysis and manuscript preparation. HC designed the study and participated in data analysis and interpretation, and manuscript preparation. All authors have read and approved the final version of the manuscript.

\section{Acknowledgements}

The authors' work is supported by National Heart, Lung and Blood Institute Grants HL-077440, HL-08157I, an American Heart Association Grant 0435I89N, an American Diabetes Association Award 7-04-RA-16, a Career Development Award from the Schweppe Foundation, and start-up funds from the University of Chicago and University of California Los Angeles (all to H. Cai).

\section{References}

I. Laing SP, Swerdlow AJ, Slater SD, Burden AC, Morris A, Waugh NR, Gatling W, Bingley PJ, Patterson CC: Mortality from heart disease in a cohort of 23,000 patients with insulin-treated diabetes. Diabetologia 2003, 46(6):760-765.

2. Paterson AD, Rutledge BN, Cleary PA, Lachin JM, Crow RS: The effect of intensive diabetes treatment on resting heart rate in type I diabetes: the Diabetes Control and Complications Trial/Epidemiology of Diabetes Interventions and Complications study. Diabetes Care 2007, 30(8):2107-2II2.

3. Goth L, Eaton JW: Hereditary catalase deficiencies and increased risk of diabetes. Lancet 2000, 356(9244): 1820-1821.

4. Rosen P, Nawroth PP, King G, Moller W, Tritschler HJ, Packer L: The role of oxidative stress in the onset and progression of diabetes and its complications: a summary of a Congress Series sponsored by UNESCO-MCBN, the American Diabetes Association and the German Diabetes Society. Diabetes Metab Res Rev 200I, 17(3): I89-2I2.

5. Sakai K, Matsumoto K, Nishikawa T, Suefuji M, Nakamaru K, Hirashima Y, Kawashima J, Shirotani T, Ichinose K, Brownlee M, et al.: Mitochondrial reactive oxygen species reduce insulin secretion by pancreatic beta-cells. Biochem Biophys Res Commun 2003, 300(I):216-222.

6. Ceriello A: New insights on oxidative stress and diabetic complications may lead to a "Causal" antioxidant therapy. Diabetes Care 2003, 26(5): I589-1596.

7. Schmidt AM, Yan SD, Wautier JL, Stern D: Activation of receptor for advanced glycation end products: a mechanism for chronic vascular dysfunction in diabetic vasculopathy and atherosclerosis. Circ Res 1999, 84(5):489-497.

8. Cai H, Harrison DG: Endothelial dysfunction in cardiovascular diseases: the role of oxidant stress. Circ Res 2000, 87(10):840-844.

9. Feener EP, King GL: Endothelial dysfunction in diabetes mellitus: role in cardiovascular disease. Heart Fail Monit 200I, I(3): $74-82$.

10. Natarajan R, Gerrity RG, Gu JL, Lanting L, Thomas L, Nadler JL: Role of I2-lipoxygenase and oxidant stress in hyperglycaemiainduced acceleration of atherosclerosis in a diabetic pig model. Diabetologia 2002, 45(1): I25-133.

II. Cai H, Griendling KK, Harrison DG: The vascular NAD(P)H oxidases as therapeutic targets in cardiovascular diseases. Trends Pharmacol Sci 2003, 24(9):47I-478.

12. Aliciguzel Y, Ozen I, Aslan M, Karayalcin U: Activities of xanthine oxidoreductase and antioxidant enzymes in different tissues of diabetic rats. J Lab Clin Med 2003, I 42(3): $172-177$.

13. Ouslimani N, Mahrouf M, Peynet J, Bonnefont-Rousselot D, Cosson C, Legrand A, Beaudeux JL: Metformin reduces endothelial cell expression of both the receptor for advanced glycation end products and lectin-like oxidized receptor I. Metabolism 2007, 56(3):308-3I3.

14. Su J, Lucchesi PA, Gonzalez-Villalobos RA, Palen DI, Rezk BM, Suzuki $Y$, Boulares HA, Matrougui K: Role of advanced glycation end products with oxidative stress in resistance artery dysfunc- 
tion in type 2 diabetic mice. Arterioscler Thromb Vasc Biol 2008, 28(8): 1432-1438

15. Hink U, Li H, Mollnau H, Oelze M, Matheis E, Hartmann M, Skatchkov M, Thaiss F, Stahl RA, Warnholtz A, et al.: Mechanisms underlying endothelial dysfunction in diabetes mellitus. Circ Res 2001, 88(2):EI4-22.

16. Oak JH, Cai H: Attenuation of angiotensin II signaling recouples eNOS and inhibits nonendothelial NOX activity in diabetic mice. Diabetes 2007, 56(I): I |8-I26.

17. Johansen JS, Harris AK, Rychly DJ, Ergul A: Oxidative stress and the use of antioxidants in diabetes: linking basic science to clinical practice. Cardiovasc Diabetol 2005, 4(I):5.

18. Potenza MA, Gagliardi S, Nacci C, Carratu MR, Montagnani M: Endothelial dysfunction in diabetes: from mechanisms to therapeutic targets. Curr Med Chem 2009, I6(I):94-II 2 .

19. Stadler K, Jenei V, Somogyi A, Jakus J: Beneficial effects of aminoguanidine on the cardiovascular system of diabetic rats. Diabetes Metab Res Rev 2005, 2 I (2): 189-196.

20. Ara C, Karabulut AB, Kirimlioglu H, Yilmaz M, Kirimliglu V, Yilmaz S: Protective effect of aminoguanidine against oxidative stress in an experimental peritoneal adhesion model in rats. Cell Biochem Funct 2006, 24(5):443-448.

21. Chowdhury P, Soulsby ME, Scott JL: Effects of aminoguanidine on tissue oxidative stress induced by hindlimb unloading in rats. Ann Clin Lab Sci 2009, 39(I):64-70.

22. Szabo C, Ferrer-Sueta G, Zingarelli B, Southan G], Salzman AL, Radi $R$ : Mercaptoethylguanidine and guanidine inhibitors of nitricoxide synthase react with peroxynitrite and protect against peroxynitrite-induced oxidative damage. J Biol Chem 1997, 272(I 4): $9030-9036$

23. Ihm SH, Yoo HJ, Park SW, Ihm J: Effect of aminoguanidine on lipid peroxidation in streptozotocin-induced diabetic rats. Metabolism 1999, 48(9): | |4|-I| |45.

24. Giardino I, Fard AK, Hatchell DL, Brownlee M: Aminoguanidine inhibits reactive oxygen species formation, lipid peroxidation, and oxidant-induced apoptosis. Diabetes 1998 47(7): I I $|4-| \mid 20$.

25. Bolton WK, Cattran DC, Williams ME, Adler SG, Appel GB, Cartwright K, Foiles PG, Freedman BI, Raskin P, Ratner RE, et al.: Randomized trial of an inhibitor of formation of advanced glycation end products in diabetic nephropathy. Am J Nephrol 2004, 24(I):32-40.

26. Thornalley PJ: Use of aminoguanidine (Pimagedine) to prevent the formation of advanced glycation endproducts. Arch Biochem Biophys 2003, 4I 9(I):3 I-40.

27. Alderton WK, Cooper CE, Knowles RG: Nitric oxide synthases: structure, function and inhibition. Biochem J 200I, 357(Pt 3):593-615.

28. Rosca MG, Mustata TG, Kinter MT, Ozdemir AM, Kern TS, Szweda LI, Brownlee M, Monnier VM, Weiss MF: Glycation of mitochondrial proteins from diabetic rat kidney is associated with excess superoxide formation. Am J Physiol Renal Physiol 2005, 289(2): $F 420-430$

29. Kuttler B, Schneider E: Diabetes mellitus in mice induced by multiple subdiabetogenic doses of streptozotocin: age and sex dependence. Acta Biol Med Ger 1982, 4I(I 2): I I99-1 202.

30. Rees DA, Alcolado JC: Animal models of diabetes mellitus. Diabet Med 2005, 22(4):359-370.

31. Shen KP, Lo YC, Yang RC, Liu HW, Chen IJ, Wu BN: Antioxidant eugenosedin-A protects against lipopolysaccharide-induced hypotension, hyperglycaemia and cytokine immunoreactivity in rats and mice. J Pharm Pharmacol 2005, 57(I): I I7-I25.

32. Tay YC, Wang Y, Kairaitis L, Rangan GK, Zhang C, Harris DC: Can murine diabetic nephropathy be separated from superimposed acute renal failure? Kidney Int 2004, 68(1):391-398.

33. Cai H, McNally JS, Weber M, Harrison DG: Oscillatory shear stress upregulation of endothelial nitric oxide synthase requires intracellular hydrogen peroxide and CaMKII. J Mol Cell Cardiol 2004, 37(I): $121-125$.

34. Chalupsky K, Cai H: Endothelial dihydrofolate reductase: critical for nitric oxide bioavailability and role in angiotensin II uncoupling of endothelial nitric oxide synthase. Proc Natl Acad Sci USA 2005, I 02(25):9056-906I.

35. Fleischhacker E, Esenabhalu VE, Spitaler M, Holzmann S, Skrabal F, Koidl B, Kostner GM, Graier WF: Human diabetes is associated with hyperreactivity of vascular smooth muscle cells due to altered subcellular Ca2+ distribution. Diabetes 1999 , 48(6): I $323-1330$

36. Chang KC, Chung SY, Chong WS, Suh JS, Kim SH, Noh HK, Seong BW, Ko HJ, Chun KW: Possible superoxide radical-induced alteration of vascular reactivity in aortas from streptozotocin-treated rats. J Pharmacol Exp Ther 1993, 266(2):992-1000.

37. El-Remessy AB, Abou-Mohamed G, Caldwell RW, Caldwell RB: High glucose-induced tyrosine nitration in endothelial cells: role of eNOS uncoupling and aldose reductase activation. Invest Ophthalmol Vis Sci 2003, 44(7):3।35-3|43.

38. Brooks BA, Heffernan S, Thomson S, McLennan SV, Twigg SM, Yue DK: The effects of diabetes and aminoguanidine treatment on endothelial function in a primate model of type I diabetes. Am J Primatol 2008, 70(8):796-802.

39. Rodriguez-Manas L, Angulo J, Vallejo S, Peiro C, Sanchez-Ferrer A Cercas E, Lopez-Doriga P, Sanchez-Ferrer CF: Early and intermediate Amadori glycosylation adducts, oxidative stress, and endothelial dysfunction in the streptozotocin-induced diabetic rats vasculature. Diabetologia 2003, 46(4):556-566.

40. Pieper GM: Enhanced, unaltered and impaired nitric oxidemediated endothelium-dependent relaxation in experimental diabetes mellitus: importance of disease duration. Diabetologia 1999, 42(2):204-213.

4I. Hopfner RL, McNeill JR, Gopalakrishnan V: Plasma endothelin levels and vascular responses at different temporal stages of streptozotocin diabetes. Eur J Pharmacol I999, 374(2):22 I-227.

42. Schofield I, Malik R, Izzard A, Austin C, Heagerty A: Vascular structural and functional changes in type 2 diabetes mellitus: evidence for the roles of abnormal myogenic responsiveness and dyslipidemia. Circulation 2002, 106(24):3037-3043

43. Bagi Z, Koller A, Kaley G: PPARgamma activation, by reducing oxidative stress, increases NO bioavailability in coronary arterioles of mice with Type 2 diabetes. Am J Physiol Heart Circ Physiol 2004, 286(2):H742-748.

44. El-Khatib AS, Moustafa AM, Abdel-Aziz AA, Al-Shabanah OA, ElKashef $\mathrm{HA}$ : Effects of aminoguanidine and desferrioxamine on some vascular and biochemical changes associated with streptozotocin-induced hyperglycaemia in rats. Pharmacol Res 200I, 43(3):233-240

45. Dewhurst M, Stevens EJ, Tomlinson DR: Effects of aminoguanidine and $N(G)$-nitro-L-arginine methyl ester on vascular responses of aortae and lungs from streptozotocin-diabetic rats. Prostaglandins Leukot Essent Fatty Acids 1997, 56(4):3 17-324.

Publish with Biomed Central and every scientist can read your work free of charge

"BioMed Central will be the most significant development for disseminating the results of biomedical research in our lifetime. "

Sir Paul Nurse, Cancer Research UK

Your research papers will be:

- available free of charge to the entire biomedical community

- peer reviewed and published immediately upon acceptance

- cited in PubMed and archived on PubMed Central

- yours - you keep the copyright 